\title{
Earnings Management in the Public Banks
}

Alwan Sri Kustono

Accounting Department, University of Jember, Jln. Kalimantan no 37, East Java, Indonesia 68121

DOI: $10.36347 /$ sjebm.2021.v08i02.003

| Received: 18.01.2021 | Accepted: 02.02.2021 | Published: 11.02.2021

*Corresponding author: Alwan Sri Kustono

\section{Abstract}

Earnings management is the company's potential or management behavior to gain profits by managing earnings according to their wishes. This study examines the effect of the board of commissioners size, independent commissioners, audit committee, leverage, and financial performance on earnings management practices in banking companies listed on the Indonesia Stock Exchange. The data used are company data for 80 firm-years, 2015-2018, with specific criteria. Five research hypotheses were analyzed using linear regression. The data shows that banking companies listed on the Indonesia Stock Exchange in the research year on average have met the Central Bank of Indonesia requirements. The test results show that financial performance variables affect earnings management. Managers tend to do earnings management by increasing their income if the value of financial performance is small or decreases. Unexpectedly, the board size, the proportion of independent boards, audit committees, and leverage do not influence earnings management. The company financially performs earnings management to increase earnings to meet the prescribed regulations and attract investors. Regulators should establish robust monitoring mechanisms to reduce the possibility of earnings management.

Keywords: Earnings management, earnings, commissionaire, leverage, financial performance.

Copyright $\odot 2021$ The Author(s): This is an open-access article distributed under the terms of the Creative Commons Attribution 4.0 International License (CC BY-NC 4.0) which permits unrestricted use, distribution, and reproduction in any medium for non-commercial use provided the original author and source are credited.

\section{INTRODUCTION}

Good Corporate Governance (GCG) principles implicitly imply transparency regarding reliable and relevant financial statement information for decision making. Financial reports aim to provide information about the financial position, performance, and changes in the financial position that is useful for many users with information about earnings. Implementing the GCG mechanism can provide adequate protection for shareholders and creditors because they believe that the implementation of the GCG mechanism in companies will make them return on their investment correctly [1].

There are three monitoring mechanisms applied to public companies. GCG is a mechanism implemented by stakeholders, leverage is the supervision of creditors, and share price with one of the determinants is financial performance as a market mechanism. Companies that implement the GCG mechanism are most likely companies that can have a good reputation. However, besides GCG, leverage is an indication of the companies. Leverage refers to the debt the company has. The debt policy is an alternative to company funding besides selling shares in the capital market. Debt that is used effectively and efficiently will increase company value. Besides, leverage also provides the possibility of monitoring by creditors.

Financial performance can also be used as a benchmark for investors to see its growth [2]. Financial performance is a measurement of the company's performance caused by the complex and challenging management decision-making process. The company's excellent financial performance dramatically influences the company's future, the ease with which the company obtains creditors, and can also affect investors' decisions to invest. Based on these various reasons, companies need to continue to improve their performance. The manager's role is very influential because managers will do various ways to show their best performance to attract investors.

Earnings management is the company's potential or behavior management to earn earnings by setting earnings following her wishes. Earnings management is thought to appear or carried out by managers or financial report makers in an organization or company's financial reporting process because they expect some benefit from their actions. Earnings management actions can cause financial statements to no longer reflect their fundamental value. 
Banks are financial institutions that have an essential role in the economy of a country. As an intermediary institution between parties with excess funds and parties requiring funds, a bank with sound financial performance is needed.

The implementation of GCG aims to create a banking system that is healthy, strong, and efficient to develop financial system stability to help boost national economic growth. The GCG mechanism in banking includes the board of commissioners, the independent board of commissioners, and the audit committee, which oversees its performance. Based on the background described above, the problem that will be identified in this study is whether the board of commissioners (board), independent commissioners (indcom), committee audit (committee), leverage (leverage), and financial performance affect earnings management.

Earnings management is a form of information asymmetry in agency theory. Agency theory describes the company as a meeting point between company owners and management. An agency relationship is a contract that occurs between the agent and the principal. The powers and responsibilities of agents and participants are regulated in a work contract with mutual consent. Agency theory assumes that agents have more information than principals. It is because the principal cannot observe the activities of the agent continuously and periodically. Because the principal does not have sufficient information about the agent's performance, the principal can never be specific about how the agent's effort contributes to the company's actual results. This situation is called information asymmetry, which is indicated to lead to earnings management.

Earnings management is done by playing with the accrual components in the financial statements because accruals are an easy component to play with according to the wishes of those who record transactions and prepare financial reports. The reason is that the accrual component is a component that does not require physical evidence of cash so that attempts to play with the size of the accrual component do not have to be accompanied by cash received or issued by the company.

Two critical perspectives can explain why earnings management is financial performance carried out by managers, namely the informational and opportunistic perspectives. The information perspective is a view that suggests that earnings management is a managerial policy to express managers' expectations about the company's future cash flows. Efforts to influence this information are made by utilizing the freedom to choose, use, and change accounting methods and procedures. The opportunist perspective is a view which states that earnings management is a manager's behavior to trick investors and maximize their wealth because they have more information than other parties.

Political costs are often the reason for earnings management, so company size positively influences it [3]. Several other researchers found negative influences [4]. Other researchers failed to find the impact of the firm size variable [5].

Leverage is considered a creditor's morning driver for tighter supervision [6]. Others show different debt motives [7]. According to them, earnings management is more due to the need to convey its future capabilities.

Earnings management is a form of information asymmetry in agency theory. It is because managers know more about the companies they manage. One way to overcome this problem is by having GCG used as a benchmark to see its stability. In GCG, aspects that include transparency, accountability, responsibility, and fairness are applied.

The GCG mechanism includes internal mechanisms, such as the board size, independent board, and the audit committee. External mechanisms are monitoring by the third party, such as markets, bonding, and debt covenant. The criteria for assessing GCG are indcom, committee, company secretaries, and ownership. Meanwhile, according to [8], several GCG mechanisms are manifested in the presence of a board of directors, committee, audit quality, and institutional ownership.

Actions in earnings management result in financial reports that are inconsistent with the company's actual circumstances. Investors do not know with certainty the financial performance results, causing investors to misinterpret these financial statements. High leverage contracts can also force managers to take earnings management actions.

The board is part of a vital GCG mechanism. In providing reliable financial reports, the critical role of the board is needed. Therefore, the board's existence will influence the quality of financial statements and is used as a proportion of the earnings management level performed by a manager. The board is also in charge of ensuring the implementation of GCG.

The first factor tested for its effect on earnings management is the size of the board. Elkalla $T$ [9] concluded that the size of the board is part of the GCG mechanism. This statement is reinforced by the opinion [5], which emphasizes that the board is a crucial GCG mechanism and will have more effective performance if it is small.

A small board will be more effective in financial performance carrying out supervisory actions 
than a large board size. The board's size is considered ineffective in financial performance carrying out its functions, resulting in decreased company performance. The board's increasing size will create difficulties in financial performance monitoring [10-12].

A large board has a different effect on earnings management actions. The board's large size causes control over management to be less effective. Management has a more significant opportunity to regulate and manage earnings: the larger the board's size and the management's weaker supervision. More earnings management actions are taken. Referring to the research results by $[1,10,11,13]$, this study predicts that board size influences earnings management. Thus the proposed hypothesis is:

H1: The size of the commissionaire board affects earnings management.

The management's interest in financial performance carrying out earnings management causes the need to monitor management quality through financial reports. The board has the duty and responsibility of overseeing the quality of the information in the financial statements prepared by management, not to diminish investor confidence.

The board's entry from outside the company increases its effectiveness in supervising management to prevent company earnings regulation and supervision. indcom can also act as mediators in disputes between internal managers and oversee management policies and advise management. It makes indcom the best position to prevent acts of earnings management and create a company with GCG so that if the proportion of indcom is large, it can undoubtedly reduce earnings management in the company $[1,14-$ 16]. Thus the hypothesis proposed is:

$\mathrm{H} 2$ : The proportion of independent commissionaire influences earnings management.

A committee is a component of the company's control system, and its role is crucial for company management. The committee is also considered a liaison between the board and shareholders, and management in handling control issues.

The committee is tasked with supervising management to provide actual results. With the committee's financial performance supervision, it will reduce management's opportunity to practice earnings management. The committee board's size will also influence the supervisory action's effectiveness so that shareholders' interests can be protected. From this explanation, the committee will reduce earnings management in the company. This statement is supported by the research results by $[5,15,17,18]$, which show that the committee affects earnings management. This study predicts that committee influences earnings management. Thus the proposed hypothesis is:

H3: The committee affects earnings management practices.

The debt policy is an alternative to company funding besides selling shares in the capital market. Debt that is used effectively and efficiently will increase company value. Leverage causes an increase in firm value. But if it is done under the pretext of attracting creditors' attention, it will trigger managers to undertake earnings management.

The higher the debt, the higher its creditors' demands and management to ensure that it can return the loan principal and interest. High leverage will result in a high financing value to maintain long-term performance. With this performance, it is expected that creditors will also have confidence in the company's management. Thus, it can fertilize the management of opportunistic behavior on the financial statements by way of earnings management. Besides, the growing interest resulting in the company's leverage ratio also will be even greater. Of course, it will ultimately reduce the company's earnings to be distributed with this large debt and interest. Management is likely to be motivated to financial performance out earnings management so that investors continue to trust the company.

The above statement is supported by the research that found that leverage, among other variables in their study, significantly affected earnings management [7, 19-22]. Based on the description above, the hypothesis formulation is:

H4: Leverage influences earnings management.

Financial performance measurement is financial performance carried out to improve and control its operational activities to compete with other companies. Financial performance measurement is also needed to determine the right strategy to achieve company goals. In other words, measuring financial performance is the foundation on which effective control stands.

Usually, sound financial performance shows that the bank has an excellent financial mechanism and high earnings and has a high capital adequacy ratio. Suppose the financial instrument is suitable, of course. In that case, the company is likely to be free from frauds such as earnings management because management does not need to take earnings management actions to give investors positive signals. It has provided positive values to investors with its financial mechanisms.

This explanation is supported by previous research conducted, which concluded that bank performance would lower earnings management practices [8, 23, 24]. Zahara and Veronica 2008 
concluded that bank performance had a significant and significant effect on earnings management practices. Based on this description, the formulation of the research hypothesis is:

H5: Financial performance influences earnings management.

\section{MATERIAL AND METHODS Types and Sources of Data}

This study's data type is pooled data, a combination of time series data and cross-section data. Data are obtained from the annual reports of banking companies in Indonesia from 2015 to 2018, obtained from electronic media www.IDX.co.id. The population used in this study are all banking companies listed on the Indonesia Stock Exchange (BEI) in 2015-2018. The determination of the sample of the company is done by using a purposive sampling method.

The dependent variable, which is the focus of this study, is earnings management. It is defined as an intervention by the management of information in the financial statements. Earnings management is proxied with discretionary accruals. Discretionary accruals use the accrual component in managing earnings because the accrual component does not require physical evidence of cash. Playing with the accrual component is not accompanied by cash received or disbursed.

Earnings management proxies discretionary accruals. Discretionary accruals are calculated by way of setting aside a total of accruals and nondiscretionary accruals. In calculating earnings management, the Modified Jones Model is used. Modified Jones Model can better detect earnings management than other models with Dechow et al. (1995).

\section{RESULTS AND DISCUSSION}

Classical assumption testing ensures that the data meet the criteria for the regression tester. The normality test aims to test whether the regression model has a normal distribution or not. In this study, statistical analysis used graphical analysis in the form of the Normal P-P Plot. The test results show that the normal p-p plot graph's diagonal lines represent the data's ideal state following a normal distribution. The points on the line are very close to the diagonal line or even attached to the line. The distribution follows the diagonal line's direction, so it can be concluded that the normality requirements for the regression model used have been met.

The multicollinearity test aims to determine whether there is multicollinearity. It is based on the Tolerance and Variance Inflation Factor value. If the Tolerance value is greater than 0.10 and the VIF value is less than 10 , then multicollinearity does not occur.

The test results on the five independent variables did not show multicollinearity symptoms. It is explained by calculating the Tolerance value of all variables that offer greater than 0.1 . The VIF value of all variables is less than 10 , so the regression model did not occur multicollinearity symptoms in this study.

The heteroscedasticity test aims to test whether there is inequality from one observation's residuals to another in the regression model. If the variance from one residual to another remains, it can be called homoscedasticity. If it is different, it is called heteroscedasticity. A good regression model is one that does not occur heteroscedasticity.

The scatter graphs show that data are randomly distributed. It is spread either above or below the number 0 on the $\mathrm{Y}$-axis. It can be concluded that there is no heteroscedasticity symptom in the regression model. It can be supposed that the regression model is eligible for predicting earnings management practices.

The autocorrelation test aims to determine whether there is a correlation between use in period $t$ and errors in period $\mathrm{t}-1$. The analytical tool used is the Durbin test - Watson statistics. A good regression model does not contain autocorrelation. Based on the autocorrelation test results, the $\mathrm{D}-\mathrm{W}$ value was 2,080 with $\mathrm{dl}=1.507$ and $\mathrm{du}=1.772$. It can be concluded that there is no autocorrelation because the value is $1,772 \leq$ $2,080 \leq 4-\mathrm{dl}=2,228$.

Table-1: Descriptive statistic

\begin{tabular}{|l|l|l|l|l|}
\hline Variables & Minimum & Maximum & Mean & St. Dev \\
\hline Earnings management & -0.3 & 0.3 & 0.04 & 0.1 \\
\hline Commisionaires board size & 2 & 9 & 5.3 & 1.9 \\
\hline Ratio of independent commisonaires & 0 & 1 & 0.5 & 0.2 \\
\hline Audit Committee & 1 & 8 & 3.8 & 1.3 \\
\hline Leverage & 0.2 & 1.1 & 0.9 & 0.1 \\
\hline Financial Performance & 0.2 & 0.5 & 0.2 & 0.1 \\
\hline
\end{tabular}

Table-1 shows the minimum value for the company's discretionary accruals is -0.3 , with a maximum of 0.3 . The company average has a positive accrual descriptive value. The commissioners' board's average size is 5.2 more than 3 , indicating that the average banking company has met the Central bank of Indonesia's requirements. The average size of the board of commissioners is 0.5 . The company has optimized 
Alwan Sri Kustono., Sch J Econ Bus Manag, Feb, 2021; 8(2): 69-76

the implementation of one of the good GCG companies in the banking sector. The average number of audit committees is 3.8 , more than three, which indicates that, on average, banks have met the requirements. The average leverage the company has is 0.9 . The average financial performance as proxied by (CAR) owned by banking companies is 0.2 . On average, banks have a good capital adequacy ratio.
This research was conducted using multiple regression analysis. Multiple regression analysis is a statistical technique through parameter coefficients to determine the independent variable's influence on the dependent variable. Hypothesis testing is financial performance on 5 (five) independent variables, whether they influence the dependent variable.

Table-2: Hypothesis Testing Results

\begin{tabular}{|l|l|l|l|l|l|l|l|l|}
\hline \multirow{2}{*}{ Model } & Unstandardized Coeff. & Std. Coeff. & T & Sig. & F & Sig. & Adj. $\mathbf{R}^{2}$ \\
\cline { 2 - 10 } & B & Std. Error & Beta & & & & & \\
\hline Constant & -0.275 & 0.112 & & -2.469 & 0.016 & 3.64 & .005 & 0.14 \\
\hline Comm. Board Size & 0.006 & 0.006 & 0.116 & 0.898 & 0.372 & & & \\
\hline Independent Comm. Proportion & 0.058 & 0.049 & 0.128 & 1.178 & 0.243 & & & \\
\hline Audit Committee & 0.008 & 0.009 & 0.112 & 0.872 & 0.386 & & & \\
\hline Leverage & 0.111 & 0.091 & 0.143 & 1.219 & 0.227 & & & \\
\hline Financial Performance & 0.767 & 0.193 & 0.484 & 3.967 & 0.000 & & & \\
\hline
\end{tabular}

The F test is model goodness of fit, which is used to test whether the regression model we make is good or significant or good or non-significant. If the model is significant, the model can be used for prediction or forecasting. On the other hand, if it is nonsignificant, the regression model cannot be used for forecasting. The results of the F test in this study can be seen in Table-2. Calculation results obtained $\mathrm{F}$ value of 3.644 and a significance value of 0.005 . Because the significance value is less than $5 \%$, it can be concluded that the regression model can be used to predict earnings management and is fit.

The coefficient of determination $\left(\mathrm{R}^{2}\right)$ measures how far the model can explain the dependent variable's variation. $\mathrm{R}^{2}$ value that is close to one means that the independent variables provide almost all the information needed to predict the dependent variable's variation. The results of the calculation of the coefficient of determination in this study are shown in Table 4.5. The coefficient of determination (adjusted $\mathrm{R}^{2}$ ) of 0.143 or $14,3 \%$, means that $14.3 \%$ of earnings management variation can be explained by interpreting the five independent variables that measure the board, indcom the committee, leverage, and financial performance. In comparison, other causes explain the remaining $85.7 \%$ outside the model in this study.

The $\mathrm{t}$ statistical test shows how far an independent variable individually explains variations in the dependent variable. The significance test of individual parameters ( $\mathrm{t}$-test) used a significance level $\leq$ $\alpha(0.05)$ in this study. If $\mathrm{t}$ count $\leq \alpha(0,05), \mathrm{Ha}$ is accepted, and if the significance of $t$ count $\geq \alpha(0.05)$, $\mathrm{Ha}$ is rejected. The t-test aims to see the effect of the independent variables partially on the dependent variable.

The research hypothesis test can be seen from the $\beta$ value and the significance of $\alpha$ below. The results of testing hypothesis 1 (one) show that the t value is -
0.898. The significance value of the board size variable is $0.372>0.05$, meaning that the board variable's size does not affect earnings management. Hypothesis 1 states that there is an influence on the board's size with earnings management is rejected.

The results of hypothesis 2 (two) testing indicate that the $\mathrm{t}$ value is 1.178 , and the significance value is $0.243>0.05$, which means that the proportion of indcom does not affect earnings management. Hypothesis 2 states that there is an effect on earnings management is rejected. Hypothesis testing 3 shows that the $\mathrm{t}$ value is -0.872 , and the significant value is $0.386>0.05$, which means that the committee does not affect earnings management. Hypothesis 3 (three), which states that there is an influence on earnings management, is rejected.

Hypothesis 4 (four) testing results indicate that the $t$ value is 1.219 , and the significant value is 0.227 > 0.05 , which means that the leverage variable does not affect earnings management. Hypothesis 4, which states that there is an effect of board size on earnings management, is rejected.

The results of hypothesis 5 (five) testing indicate that the t-value is 3.967 , and the significant value is $0.000<0.05$, which means that the financial performance variable affects earnings management. Hypothesis 5, which states that there is an influence on earnings management, is accepted.

\section{DISCUSSION}

The partial test calculation results show that the board's size has a significance level greater than $0.05(0.372>0.05) . \mathrm{H} 1$, which states that the size of the board affects earnings management, is rejected. However, these test results are contrary to the research by $[25,26]$, which shows that board size influences earnings management. 
These findings are not consistent with the prediction that board size influences earnings management. The following analysis can explain the test results in this study. The size of the board of commissioners is not a dominant element in the effectiveness of the commissioners. Board effectiveness is influenced by the composition, characteristics, and structure of the board. The effect of the number of board members on smoothing may not see other elements' potential consequences. The board of commissioners' role can be seen from the board of commissioners' composition and structure. Their size can influence engineering advantage if good board composition and structure support them.

The t-test results indicate that the proportion of indcom has a significance level greater than 0.05 $(0.243>0.05)$. This finding succeeded in rejecting the second hypothesis (H2), which states that the proportion of indcom affects earnings management. This research is supported by research that shows that the proportion of indcom does not involve earnings management. This study's results are inconsistent with research that states that the proportion of indcom influences earnings management [16, 27, 28].

Based on the theory, the board's proportion consists of members from outside the company [29, 30]. It tends to influence earnings management because the ratio of indcom can contribute to the quality financial statement preparation process or the possibility of avoiding it. However, these findings do not agree with this theory. Because banking companies fulfill the proportion of indcom to comply with regulations governing the ratio of indcom in each bank, this causes the indcom not work optimally to reduce earnings management.

The existence of an indcom is less effective in reducing earnings management [17]. The addition of indcom is only possible to comply with the formal obligation. The independent board size required at least $50 \%$ (five-thirty percent) of the number of commissioners. The majority shareholder still plays a vital role so that the board's performance is not increased even decreased.

The t-test results show that the committee's proportion has a significance level greater than 0.05 $(0.386>0.05)$. This finding succeeds in rejecting the second hypothesis (H3), which states that the committee affects earnings management. The results of this study are inconsistent with research from [10, 15, 18, 31, 32], which state that the committee influences earnings management.

The committee in companies can reduce earnings management activities within the company. The committee has to assist the independent commissioner in overseeing its management to influence earnings management actions. However, these findings do not agree with this theory.

The compliance with the committee by banking companies is only to comply with the regulations governing the committee at each bank regarding the mandatory committee membership must consist of at least three people, including the chairman of the committee. The function of the committee and its role is ineffective. One possibility that the committee does not financial performance carry out its duties and roles effectively is that the committee meetings are rarely attended. The problems that occur within the company and the financial reporting process are not revealed. The committee does not know.

The t-test results show that leverage has a significance level greater than $0.05(0.227>0.05)$. This finding succeeds in rejecting the second hypothesis (H4), which states that leverage influences earnings management. This study's results are inconsistent with the research finding that leverage influences earnings management $[6,20,33]$.

This study's findings are not following the prediction that the company's leverage affects earnings management financial. As already explained, leverage shows the debt ratio owned by the company. It is thought to be because many investors now know that debt or loan to the company from creditors is not the only primary source of company operations. Companies experiencing financial difficulties may meet funding needs from other sources, such as the use of retained earnings and issuance of shares that add to equity. Companies get relatively cheap funds with lower capital costs, and capital costs can be reduced. So that management is not motivated to do earnings management through the leverage variable.

The t-test results show that financial performance has a significance level smaller than 0.05 $(0.000<0.05)$. Positive beta values indicate a positive influence between financial performance on earnings management. Hypothesis 5 (five) that states that financial performance influences earnings management, has been accepted.

This study's results are consistent with previous researches $[34,35]$. They state that financial performance influences earnings management. However, this does not follow the previous allegations that managers tend to perform earnings management by raising their earnings if the value of financial performance is small or decreased (negative effect).

Suppose the value of the financial performance in meeting a bank's risk-weighted assets is high. In that case, it can automatically be said that the bank is healthy or if the capital adequacy ratio (financial performance) in meeting the bank's risk-weighted 
assets is low. It can be said that the bank is an unhealthy bank. A healthy bank with a high capital adequacy value certainly has increased earnings, and vice versa, because earnings are one of the capital formation components.

It can also be proven by the results of research that show the average value of discretionary accrual. If the company increases earnings, it also results in a high value of its capital adequacy. It is possible to meet risky assets. It can be seen from the results of this study that the financial performance value is $17 \%$. Central banks' regulations require a banking company to have a financial performance value of at least $8 \%$. The company financially performs earnings management in the form of increased earnings to meet the prescribed regulations and attract investors.

\section{CONCLUSION}

This study aims to test whether the board of commissioners, independent commissioners, committee audit, leverage, and financial performance affect earnings management. There are five hypotheses examined. There is not an influence on the board's size with earnings management. Hypothesis 1 rejected. The proportion of independent commissionaire does not affect earnings management. Hypothesis 2 is rejected. The committee does not affect earnings management. So as hypothesis 3 is rejected. Hypothesis 4, which states that there is an effect of board size on earnings management, is rejected. The study managed to prove that the financial performance variable affects earnings management. Hypothesis 5 is accepted. The variables of GCG, as proxied by the board's size, the proportion of the independent board, the committee, and leverage, do not affect earnings management. The financial performance variable which is affects earnings management. Managers tend to perform earnings management by raising their earnings if the value of financial performance small or decreased. The company financially performs earnings management in the form of increased earnings to meet the prescribed regulations and attract investors.

Banks listed on the Indonesia Stock Exchange, on average, have met the Indonesia Central Bank's requirements. The minimum number of commissioners can explain that the company must have as many as 3 (three). The proportion of independent commissioners is at least $50 \%$ of the board of commissioners' total size. The audit committee consists of at least 3 (three) auditors. The average minimum of CAR is $8 \%$.

\section{REFERENCES}

1. Kustono AS, Effendi R. Earnings Management and Corporate Governance Case in Indonesia. Adv Sci Lett. 2016;22(12):4345-7.

2. Kustono AS. How Total Quality Management Mediates Antecedent Variables of Employee
Performance? J Asian Financ Econ Bus. 2020;7(12):523-34.

3. Nalarreason K, T. S, Mardiati E. Impact of leverage and firm size on earnings management in Indonesia. Int J Multicult Multireligious Underst. 2019;6:19.

4. Rusmin R. Effects of audit quality, culture value, and firm' size on earnings reporting quality. J Akunt Audit Indones. 2014;18(1):1-15.

5. Laily N. The effects of good corporate governance and audit quality on earnings management. J Account Bus Educ. 2017;1(1):134.

6. Tulcanaza-Prieto AB, Lee Y, Koo JH. Effect of leverage on real earnings management: Evidence from Korea. Sustain. 2020;12(6).

7. Chou D, Lin JRP, Chan C, Chang S. The impact of earnings management on the choice of debt maturity structure. Manage Rev. 2011;30(Oct):137-51.

8. Mahrani M, Soewarno N. The effect of good corporate governance mechanism and corporate social responsibility on financial performance with earnings management as a mediating variable. Asian J Account Res. 2018;3(1):41-60.

9. Elkalla T. An Empirical Investigation of Earnings Management in the MENA Region A thesis submitted in partial fulfilment of the requirements for the degree of Doctor of Philosophy University of the West of England Submitted by: Tarek Elkalla Supervisors : Professor. Univ West Engl. 2017;(June):1-393.

10. Abata MA, Migiro SO. Corporate governance and management of earnings: Empirical evidence from selected Nigerian-listed companies. Invest Manag Financ Innov. 2016;13(2):189-205.

11. Mashayekhi B, Bazaz MS. The effects of corporate governance on earnings quality: Evidence from Iran. Asian $\mathrm{J}$ Bus Account. 2010;3(2):71-100.

12. Aygun M, Ic S, Sayim M. The Effects of Corporate Ownership Structure and Board Size on Earnings Management: Evidence from Turkey. Int J Bus Manag. 2014;9(12):123-32.

13. Omrani AA. Evaluating the modifying effect of corporate governance on the relationship between free cash flow and earnings management of companies listed in Tehran Stock Exchange. Int $\mathrm{J}$ Humanit Cult Stud [Internet]. 2016;Special $\mathrm{Fe}(1)$ :104-18. Available from: http://www.ijhcs.com/index.php/ijhcs/index

14. Kurniasih L, Suranta S. Journal of Finance and Banking Review Earnings Management, Corporate Governance and Tax Avoidance: The Case in Indonesia. J Fin Bank Rev [Internet]. 2017;2(4):28-35. Available from: www.gatrenterprise.com/GATRJournals/index.ht $\mathrm{ml}$

15. Utomo SD, Machmuddah Z, Oktafiyani M. The associations between earnings management, corporate environmental disclosure, corporate 
Alwan Sri Kustono., Sch J Econ Bus Manag, Feb, 2021; 8(2): 69-76

financial performance and corporate governance mechanisms. WSEAS Trans Bus Econ. 2019;16:345-54.

16. Nuryana Y, Surjandari DA. The effect of good corporate governance, and earning management on company financial performance. Glob J Manag Bus Res Account Audit. 2019;19(1):26-39.

17. Kustono AS. Corporate governance mechanism as income smoothing suppressor. Accounting. 2021;7:1-10.

18. Kapoor N, Goel S. Do diligent independent directors restrain earnings management practices? Indian lessons for the global world. Asian $\mathbf{J}$ Account Res. 2019;4(1):52-69.

19. Warrad LH. The Influence of Leverage and Profitability on Earnings Quality: Jordanian Case. Int J Acad Res Bus Soc Sci. 2017;7(10):62-81.

20. Ghazali AW, Shafie NA, Sanusi ZM. Earnings Management: An Analysis of Opportunistic Behaviour, Monitoring Mechanism and Financial Distress. Procedia Econ Financ [Internet]. 2015;28(April):190-201. Available from: http://dx.doi.org/10.1016/S2212-5671(15)01100-4

21. Ekaterina M. Debt covenants violation and earnings management. University of Vaasa; 2010.

22. Kwon KH, Lee NR. A case study on big bath earnings management with large shareholder changes with a focus on the setting of loan loss allowances for a savings bank. J Appl Bus Res. 2016;32(6):1793-808

23. Lestari N, Aeni N. The Effect of Audit Quality and Earnings Management On Firm Performance. 2019.

24. Paiva IS. Contracting debt and the quality of financial reporting in private firms. Contaduria y Adm. 2018;63(2):1-18.

25. Obigbemi IF, Omolehinwa EO, Mukoro DO, BenCaleb E, Olusanmi OA. Earnings management and board structure: Evidence from Nigeria. SAGE Open. 2016;6(3).

26. Al Azeez HAR, Sukoharsono EG, Roekhudin, Andayani W. The impact of board characteristics on earnings management in the international Oil and Gas Corporations. Acad Account Financ Stud J. 2019;23(1):1-26.

27. Yang CY, Tan BL, Ding X. Corporate governance and income smoothing in China. J Financ Report Account. 2017;10(2):120-39.

28. Huang Z, Xue Q. Re-examination of the effect of ownership structure on financial reporting: Evidence from share pledges in China. China J Account Res [Internet]. 2016;9(2):137-52. Available from: http://dx.doi.org/10.1016/j.cjar.2015.11.001

29. Shaique M, Guo F, Shaikh R, Khan S, Usman M. Role of social relations of outside directors with CEO in earnings management. Int J Financ Stud. 2017;5(4):34.

30. Alves S. The effect of board independence on the earnings quality: Evidence from portuguese listed companies. Australas Accounting, Bus Financ J. 2014;8(3):23-44.

31. Gasteratos I, Karamalis M, Koutoupis A, Filos I. Earnings Management in Greece: A Case Study in Construction Sector Using Jones Model. Int J Econ Bus Adm. 2016;IV(Issue 4):3-16.

32. Suryanto T, Thalassinos JE, Thalassinos EI. Board Characteristics, Audit Committee and Audit Quality: The Case of Indonesia. Int J Econ Bus Adm. 2017;V(Issue 3):44-57.

33. Shah K, Shah A. The Impact of Corporate Governance and Ownership Structure on Earnings Management Practices: Evidence from Listed Companies in Pakistan. Lahore $\mathrm{J}$ Econ. 2014;19(2):27-70.

34. Rossi PR. Earnings management in India. CFA Dig. 2014;44(3).

35. Chen S, Wang Y, Zhao Z. Regulatory Incentives for Earnings Management through Asset Impairment Reversals in China. J Accounting, Audit Financ [Internet]. 2009 Oct 1;24(4):589620. Available from: https://doi.org/10.1177/0148558X0902400405. 